\title{
Changes in Strength and Chemical Contents of Oil Heat Treated 15-year-old Cultivated Acacia Hybrid
}

\author{
Razak Wahab (Corresponding author) \\ Faculty of Agro Industry \& Natural Resources, Universiti Malaysia Kelantan \\ 17600 Jeli, Kelantan, Malaysia \\ Tel: 60-19-862-8787 E-mail: razak@umk.edu.my \\ Izyan Khalid
}

Faculty of Agro Industry \& Natural Resources, Universiti Malaysia Kelantan

17600 Jeli, Kelantan, Malaysia

Tel: 60-12-400-5712 E-mail: izyan@umk.edu.my

Mahmud Sudin

School of International Tropical Forestry, Universiti Malaysia Sabah, 88999

Kota Kinabalu, Sabah, Malaysia

Tel: 60-13-886-0049 E-mail: mudsudin@ums.edu.my

Mohd Sukhairi Mat Rasat

Universiti Teknologi MARA, Bandar Jengka, 26400 Pahang, Malaysia

Tel: 60-17-829-9042Ｅ-mail: mohdsukhairi@yahoo.com

Othman Sulaiman

School of Industrial Technology, Universiti Sains Malaysia, 11800 Penang, Malaysia

Tel: 60-16-470-8134Ｅ-mail: othman@usm.my

Tamer A. Tabert

School of International Tropical Forestry, Universiti Malaysia Sabah, 88999

Kota Kinabalu, Sabah, Malaysia

Tel: 60-10-941-7104 E-mail: tamertbt@ums.edu.my

Received: March 23, 2011

Accepted: April 4, $2011 \quad$ Published: April 1, 2012

doi:10.5539/ijc.v4n2p90

URL: http://dx.doi.org/10.5539/ijc.v4n2p90

\begin{abstract}
Studies were conducted on the changes in strength and chemical contents of cultivated 15 year-old Acacia hybrid treated through oil heat treatment process. The timbers harvested and cut at the portions bottom, middle and top, were oil heat treated using palm oil for durations of 30, 60 and $90 \mathrm{~min}$. at temperatures of 180,200 and $220{ }^{\circ} \mathrm{C}$. The untreated $A$. hybrid was used as control. The results of the studies showed that the oil heat treatment process causes some changes in the strength and chemical composition of the timbers. Strength reduction during the bending tests in both the MOR and MOE were noted throughout the treatment process. The chemical constituents of the treated timber also underwent changes in their contents. The holocellulose and cellulose degraded with the increasing of treatment temperature and duration in the oil heat treatment, while lignin showed
\end{abstract}


the increment in content through this treatment. The changes in values of both the strength and chemical contents were influenced by temperature and duration of the treatment.

Keywords: Oil heat treatment, Cultivated Acacia hybrid, Strength reduction, Chemical contents changes

\section{Introduction}

Forest plantation has becomes an important sources in providing sustainable supply of raw materials to the Malaysian wood-based industry. This is due to the declining supply of timbers from the natural forests. This is further aggravated by the consumers demand in Europe and North America of getting supplies of timber with green products certification and their sensitivity about logging activities of naturally grown species from tropical rainforest. Plantation forestry provide attractive investments for the government and private sectors because of their short rotation compared to that of the natural stands.

Forest plantation project started in 1982 with Acacia species aimed at sustaining the supply of timber to the industries which was expected to face a shortfall from the natural forests (Shakri, 1995). Acacia species was chosen due to its rapid growth and easy adaptation to the Malaysian soil conditions (Pinyopusarerk et al., 1993). Acacia hybrid is classified under the slightly durable category, the wood requires preservative to prolong its use especially when used in exposed condition and in ground contact uses. However, wood preservative contains heavy metals which pollute the environment. Furthermore, most of the developed countries have banned the imported and usage of timber impregnated with copper chrome arsenic (CCA). The use of oil heat treatment which is considered environment friendly has become an alternative to enhance the durability of timber (Rafidah et al., 2009; Razak et al., 2005). This treatment uses hot oil as the medium of heat transfer and altered the main wood chemicals composition in treated wood.

The objectives of this study were to investigate the changes that occurred in the strength properties and main chemical contents as the results of the oil heat treatment process on the cultivated $A$. hybrid. The strength properties and the chemical contents are important parameters that influenced durability and stability of the wood. The results of this study will be of advantage and beneficial to the Malaysian wood-based the industry.

\section{Materials and Methods}

\subsection{Materials}

Cultivated $A$. hybrid of age 15-year-old were harvested from the Sabah Forest Development Authority plantation in Kinarut, Sabah, Malaysia. The trees were randomly selected based on their age, physical characteristics, dbh diameter between 250-300 $\mathrm{mm}$ and having long straight boles. The trees were felled, cut and segregated into three height portions, namely, the bottom, middle and top, corresponding to $50 \%, 30 \%$ and $20 \%$ of the merchantable height respectively. Blocks of $600 \mathrm{~mm}$ long were cut from the middle of each portion. The wood blocks were then transported to Universiti Malaysia Sabah for further processing and subsequent testing.

\subsection{Sample Preparation}

All wood blocks were initially air dried at room temperature for about a month to reduce the moisture to equivalent moisture content $(15 \%)$ and to remove stresses in them. After drying, the wood blocks were planed into sizes of $300 \mathrm{~mm} \times 100 \mathrm{~mm} \times 25 \mathrm{~mm}$ (length $\times$ width $\times$ thickness) for the oil heat treatment process. These samples were mixture of sapwood and heartwood.

\subsection{Hot Oil Treatment Process}

$A$. hybrid samples were oil heat treated in a stainless steel tank attached to the heat treatment machine. The temperatures of the oil and the wood samples were control through a control panel located out-side the tank. An electric generator was used to generate heat. Prior to treatment, the wood samples were stabilized to $12 \%$ moisture content in a conditional chamber set at $65 \%$ relative humidity and temperature $25{ }^{\circ} \mathrm{C}$. Eighty (80) woods were prepared prior to the treatment. Weight of the woods was recorded before and after treatment to determine weight loss caused by the treatment. The tank was filled with the oil until it reached three quarters full. Treatment temperature was set at 180,200 and $220{ }^{\circ} \mathrm{C}$ for 30,60 and $90 \mathrm{~min}$. The samples were initially placed into hot oil at $80{ }^{\circ} \mathrm{C}$ and real treatment time started when the oil bath reached target temperature. The temperatures were recorded every 10 min respectively. After each treatment period, the wood samples were removed from the tank and wiped with a clean cloth to avoid excessive oil seeping into wood tissues. The samples were then cooled and later conditioned in a conditioning chamber at $25 \pm 2{ }^{\circ} \mathrm{C}$ and $65 \pm 5 \%$ relative humidity before reweighing. The wood samples were later cut into various sizes for respective testing for strength and chemical analysis tests. The procedure outlines by Razak et al. (2011), Izyan et al. (2010) and Rafidah et al. (2009) were followed for the wood treatment and testing. 


\subsection{Strength Properties (Modulus of Rupture and Modulus of Elasticity in Static Bending)}

A Universal Testing Machine located in Forest Research Center, Sandakan, Sabah, was used for bending testing. The evaluation for the static bending of the wood was conducted with ASTM D4761 (1999) standard. The dimensions of wood samples for static bending test were $20 \times 20 \times 300 \mathrm{~mm}$. The specimen was supported on a span of $280 \mathrm{~mm}$ and the force applied at mid-span using a loading head. The rate of loading was $6.6 \mathrm{~mm} / \mathrm{min}$. Wood were loaded on the radial surface. The tests were stopped once the wood started to break. The proportional limit and ultimate load and deflection were recorded, and the MOE and MOR were calculated automatically by the computer connected to the machine.

\subsection{Chemical Properties}

The chemical changes studied were holocellulose, cellulose, hemicellulose and lignin. All chemical analysis tests were conducted separately for heartwood and sapwood. The total amounts of chemical constituents were calculated based on the sapwood or heartwood ratios. Evaluation of chemical analysis was conducted using TAPPI T203 cm-99 (TAPPI 1999) and TAPPI T222 cm-02 (TAPPI 2002) standards.

\section{Result and Discussion}

\subsection{Strength Properties (MOR and MOE in Bending Tests)}

The result of strength properties of treated $A$. hybrid wood is presented in Table 1. It was clearly observed the values of both wood types (sapwood and heartwood) for modulus of rupture (MOR) and modulus of elasticity (MOE) decreased through oil thermally modified. The untreated wood still obtained the highest strength values compared to treated wood. The strength properties of wood usually decrease with increasing temperature and increase with decreasing temperature (Smith et al., 2003).

For the thermally modified wood, the highest values of MOR and MOE of every portion started to decreased when the treatment temperature reaching $180{ }^{\circ} \mathrm{C}$. This strength values respectively decreased when treated at $200{ }^{\circ} \mathrm{C}$ and $220{ }^{\circ} \mathrm{C}$. From the results obtained the values of MOR and MOE of untreated and treated wood showed a decrement with increasing sampling height. The variations in MOR and MOE along the tree height can be explained by the decrease in maturity of wood and fibre length from the base to the top of the tree (Rulliarty \& America, 1995). Wood treated at 180 to $200{ }^{\circ} \mathrm{C}$ in the presence of moisture resulted in a large reduction in the resistance to MOR, MOE and compression strength (Giebler, 1983). While other researcher reported that at temperature over $200{ }^{\circ} \mathrm{C}, \mathrm{MOE}$ and MOR of wood can be reduced by up to $50 \%$ (Bekhta \& Niemz, 2003; Sailer et al., 2000; Kamden et al., 1999). The increased treatment duration which is 30 to 90 minutes also prolong the decreasing effect on strength. The higher the temperature the longer the treatment duration the lower is the strength value.

The strength properties of the oil heat treated wood are reduced by thermal modification but the dimensional stability and biological durability of wood is increased without having to add outside chemicals to the wood (Yildiz et al., 2006). The diminutions in the strength properties were related to the rate of thermal degradation and losses of substances after heat treatment (Rusche, 1973). The decrease in strength is mainly due to the depolymerization reactions of wood polymers (Kotilainen, 2000), where changes in or loss of hemicelluloses play key roles in the strength properties of wood heated at high temperatures (Hillis, 1984). Kocaefe et al. (2007) also noted that the change in mechanical properties of wood especially in strength at high temperature is mainly due to the hemicelluloses degradation. It has a lower molecule weight compared to the other wood polymers, therefore it degrades faster. Thus, the cellulose crystallization and lignin modification take place (Wikberg \& Maunu, 2004).

The application of high temperatures has negative effect on degradation consequently on the strength properties (Kocaefe et al., 2007). The heat treatment affected lignin and hemicelluloses and resulted in water soluble polymer formation (Stamm, 1946). The moisture content, treatment temperature, presence and absence of oxygen and treatment time are the factors, which influence most the hydrolysis reactions, consequently the mechanical properties. However, the effects on strength decreases are different for each species, anatomical features and treatment methods (Mburu et al., 2008; Kocaefe et al., 2007).

Studies on the effect of high temperature on spruce wood found that MOE of spruce wood decrease when the treatment temperature rose over $100{ }^{\circ} \mathrm{C}$ (Bekhta \& Niemz, 2003). At low temperatures up to approximately $100{ }^{\circ} \mathrm{C}$, only minor changes occur in the mechanical properties of wood, however, strength properties of wood start to weaken and become brittle when treatment temperatures reach over $200{ }^{\circ} \mathrm{C}$ (Sundqvist, 2004). The compression failure usually occurs in wood with low density (Nurdahlia, 2008; Bodig \& Jayne, 1982). The reduction of density in the treated material can caused reduction in some of the strength properties (Rafidah, 
2008; Janssen, 1981). Strength loss increases with increased treatment temperature and time. Hence the use of heat-treated wood in load bearing constructions is restricted due to bending and tension strength decrease by 10 to $30 \%$ (Korkut et al., 2007; Jamsa \& Viitaniemi, 2001).

\subsection{Chemical Properties}

The chemical contents of the treated Acacia wood before and after undergoing the hot oil treatment process is shown in Table 2. Both the control sapwood and heartwood had the highest chemical contents of holocellulose and cellulose when compared with the oil heat treated wood at various treatment temperature and time. The results clearly showed that the changes of chemical contents occurred when the wood were treated at higher temperature and duration. At temperature above $180{ }^{\circ} \mathrm{C}$, the treated wood experiences losses of polysaccharide material (Hill, 2006).

\subsubsection{Holocellulose}

Slight reduction on the holocellulose contents in the treated sapwood and heartwood occurred with the increasing of treatment temperature and time in comparison to both untreated sapwood and heartwood. The holocellulose contents ranged between 63.1 to $70.8 \%$ for sapwood and 64.0 to $71.7 \%$ for heartwood depending on the temperature and duration applied. Studies by Inari et al. (2007) and Boonstra and Tjeerdsma (2005) also reported similar observations. The holocellulose content of beech and pine decreases between $50 \%$ and $60 \%$ after heat treatment (Inari et al., 2007). While Boonstra and Tjeerdsma (2005) found that holocellulose content of heat treated Scots pine decreased between $79.7 \%$ and $63.3 \%$. The decreases in the holocellulose content occurred when the wood were heated at a temperature above $100{ }^{\circ} \mathrm{C}$ (Hill, 2006). The content decrease is associated with the loss of cellulose and hemicellulose during the process.

\subsubsection{Cellulose}

Cellulose content determined for both wood types after heat treatment were between $98 \%$ and $80 \%$ for sapwood, while the values for heartwood were between $97 \%$ and $78 \%$. The result showed that minor degradation of celluloses can be seen when wood treated at $180{ }^{\circ} \mathrm{C}$ in $30 \mathrm{~min}$ and it continually to decrease with the increase of temperature and time of treatment. Cellulose is more resistant to hydrolysis than hemicelluloses, pectins and starch, and it has generally a more regular and crystalline structure with considerably higher molecule weight (Sundqvist, 2004). From the analysis of molecule size of cellulose in heat treatment by using intrinsic viscosity measurement, it showed that heat treatment results in a considerable reduction in molecule size of cellulose. As stated by Yilidz et al. (2006), crystalline structure of cellulose is not changed or even can improve up to a certain temperature, which may be as high as $200{ }^{\circ} \mathrm{C}$ depending on the conditions involved as in an agreement by Boonstra and Tjeerdsma (2005) which stated that different process conditions and treatment time applied during heat treatment can influence degradation rate of cellulose content. Fengel and Wegener (1989) found that the degree of polymerization of cellulose is already decreased in thermally treated spruce at temperatures above $120{ }^{\circ} \mathrm{C}$ due to cleavage of the glucosidic bonding that is accelerated by the presence of acids that are catalyzing the reaction. With extended heating, chain scission of the cellulose occurs, producing alkaline soluble oligosaccharides, with a concomitant decrease in the cellulose DP and degree of cyrstallinity (Hill, 2006). $\mathrm{CO}_{2}$ and $\mathrm{CO}$ are produced when cellulose is heated at $170{ }^{\circ} \mathrm{C}$ (Shafizadeh, 1984) and heating for a longer periods results in an increase in carbonyl groups at the expense of carboxylic moieties (Fengel \& Wegener, 1989).

\subsubsection{Hemicellulose}

Hemicelluloses content for both heat treated sapwood and heartwood showed fluctuation in values, but showing no specific trend. The hemicelluloses for sapwood experiences changes in content from $24.4 \%$ in control to $26.1 \%$ in heat treated samples. While in the heartwood the content changes from $24.5 \%$ to $26.2 \%$. Both wood experiences an increases in the hemicelluloses contents. Mburu et al. (2008) found that the increment in lignin content of Grevillea robusta wood with treatment time confirming higher susceptibility of hemicelluloses to thermal treatment. Rowell et al. (2005), stated that hemicelluloses change is predominate at temperatures below $200{ }^{\circ} \mathrm{C}$. The lower thermal stability of hemicellulose compared to cellulose is usually explained by the lack of crystallinity (Kotilainen, 2000), When wood is heated, the most thermally labile of the hemicelluloses begin to degrade, resulting in the production of methanol, acetic acid and various volatile heterocyclic compounds (Hill, 2006). The acetic acid is generated when the acetylated hydroxyl groups of the hemicellulose chains are split off (Johansson, 2008). It is suggested that volatile organic acids formed due to heating of wood are trapped in the process and promote the degradation rate (Viitaniemi, 2001). 


\subsubsection{Lignin}

The lignin content of sapwood and heartwood in the $A$. hybrid increased with an increase in treatment temperature and duration. An increment in lignin content of the sapwood from $20.8 \%$ in the untreated wood to $24.7 \%$ in the heat treated wood, while the lignin content of the heartwood from $22.4 \%$ in the untreated heartwood to $25.0 \%$ in the heat treated wood. Similar observations were also made by Brito et al. (2008), Mburu et al. (2008), Inari et al. (2007), Yildiz et al. (2006) and Sarni et al. (1990). The changed in lignin composition showed that there was a changed in the lignin structure of wood. The loss of polysaccharides material during the heat treatment leads to an increase in the lignin content of the wood (Sandermann \& Augustin, 1964).

\subsubsection{Analysis of Variance and Correlation Coefficient between the Strength and Chemical Properties}

The analysis of variance for the strength properties are shown in Tables 3. The analysis was conducted to determine whether there was significance difference between physical properties with treatment temperatures, duration, wood types and sampling height. There were significant difference between moisture content with treatment temperatures, duration and wood types. However there was no significant difference between moisture content and sampling height (bottoms towards the top) of the tree. For basic density, there were significant difference was observed with treatment temperatures, duration, wood types and sampling height.

The analysis of variance indicated that for MOR there are significant differences in treatment temperature, duration of treatment and sampling height. However, there is no significant difference in the wood type. For MOE, only two significant differences were observed, which are treatment temperature and wood types. There is no significant difference in duration of treatment and sampling height.

The ANOVA (see Table 4) showed that there was a significant difference between the temperatures and duration of the treatment relating to content of lignin. Almost all of the chemical components were significantly affected by temperature, treatment duration and wood types. There were a significant difference between the treatment temperature, duration and wood type of the treatment relating to the content of holocellulose, cellulose and lignin. Therefore, it can be concluded that the effects of temperature, treatment duration and wood types were a caused of the change in chemical composition of those chemical component. For the hemicellulose, the ANOVA showed that there was no significant difference with wood type of the treatment relating to the content of hemicellulose. The wood types did not affect the changed in hemicellulose content in oil thermally modified process. The effects of temperature and treatment duration were a cause of decrement of hemicellulose composition. Changes in the chemical contents of the wood occurred with the increases in temperature. The chemical composition in $A$. hybrid wood is highly affected by treatment temperature, duration and wood types in oil thermally modified process.

The correlation between the strength and chemical properties are presented in Table 5. There was a correlation between the strength properties (MOR and MOE) and chemical composition of Acacia wood. There were a correlation between MOR and MOE and chemical composition of treated wood. Positive correlation was obtained between MOR and MOE, holocellulose and cellulose, while hemicellulose and lignin were negatively correlated with MOR. For MOE there was also a correlation between chemical contents of treated wood. Positive correlation was obtained between MOE, holocellulose and celluloses, while the hemicellulose and lignin were negatively correlated with MOE.

\section{Conclusions}

1) The strength properties of the oil heat treated $A$. hybrid wood were reduced during the treatment process. Both the MOR and MOE in the bending tests decreases throughout the treatment process and were influenced by the increases in the treatment temperature and duration.

2) The main chemical composition of the treated $A$. hybrid wood experienced changes in their contents. Holocellulose, celulose and hemicellulose contents degraded with the increasing of treatment temperature and time of heating exposure, while lignin showed the increment in content through this treatment.

3) The increase in the holocellulose and cellulose contents causes an increase in the strength (MOR and MOE) of the $A$. hybrid wood. On the other hand, the reduction of the hemicellulose and lignin contents causes the drop in strength of the hot oil treated $A$. hybrid.

\section{Acknowledgement}

The research was financed by The Ministry of Science, Technology and Invention, Malaysia, under the Science Fund Project SCF0037-IND-1/2007. 


\section{References}

Ahmad Shakri, M. S. (1995). Finishing Properties of Acacia mangium, Paraserianthes falcataria and Gmelina arborea Timbers: Some Important Parameters. Journal of Tropical Forest Products, 1(1), 83-89.

American Society for Testing and Material. (1999). ASTM D4761-05: Section 4: Construction. Volume 04.10: Wood. West Conshohocken, Pennsylvania.

Bekhta, P., \& Niemz, P. (2003). Effect of High Temperature on the Change in Color, Dimensional Stability and Mechanical Properties of Spruce Wood. Journal of Holzforschung, 57, 539-546. http://dx.doi.org/10.1515/HF.2003.080

Bodig, J., \& Jayne, B. A. (1982). Mechanics of Wood and Wood Composite. Van Nostrand Reinbold Co. New York, USA.

Boonstra, M. J., \& Tjeerdsma, B. (2005). Chemical Analysis of Heat Treated Softwoods. Journal of Holz als Roh-und Werkstoff, 64(3), 204-211. http://dx.doi.org/10.1007/s001007-005-0078-4

Brito, J. O., Silva, F. G., Leao, M. M., \& Almeida, G. (2008). Chemical Composition Changes in Eucalyptus and Pinus Woods Submitted to Heat Treatment. Journal of Bioresource Technology, 99(18), 8545-8548. http://dx.doi.org/10.1016/j.biortech.2008.03.069

Fengel, D., \& Wegener, G. (1989). Wood Chemistry, Ultrastructure, Reactions. Walter de Gruyter and Co. Berlin, New York.

Giebeler, E. (1983). Dimensional Stabilization of Wood by Moisture-heat-pressure. Journal of Holz als Roh-und Werkstoff, 41(3), 87-94. http://dx.doi.org/10.1007/BF02608498

Hillis, W. E. (1984). High Temperature and Chemical Effects on Wood Stability. Part 1: General Considerations. Journal of Wood Science and Technology, 18(4), 281-293. http://dx.doi.org/10.1007/BF00353364

Hill, C. A. S. (2006). Wood Modification: Chemical, Thermal and Other Processes. John Wiley \& Sons, Ltd. England. http://dx.doi.org/10.1002/0470021748

Inari, G. N., Petrissans, M., \& Gerdin, P. (2007). Chemical Reactivity of Heat-treated Wood. Journal of Wood Science and Technology, 4l(2), 157-168. http://dx.doi.org/10.1007/s00226-006-0092-7

Izyan, K., Razak, W., Mahmud, S., Othman, S., Affendy, H., Hanim, R. A., \& Andy, R. M. (2010). Chemical Changes in 15 year-old Cultivated Acacia hybrid Oil heat Treated at 180, 220 and $220{ }^{\circ} \mathrm{C}$. International Journal of Chemistry, 2(1), 97-107. ISSN: 1916-9701. Canadian Center of Science and Education.

Jams, A. S., \& Viitaniemi, P. (2001). Heat Treatment of Wood Better Durability without Chemicals. Review on Heat Treatments of Wood. Cost Action E22. Proceedings of the Special Seminar, Antibes, France. pp. 17-22.

Janssen, J. A. (1981). Bamboo in Building Structures. Ph.D. Thesis. University of Technology, Holland.

Johansson, D. (2008). Heat Treatment of Solid Wood; Effects on Absorption, Strenght and Colour. Ph.D. Thesis. Lulea University of Technology. ISSN: 1402-1544.

Kamden, D. P., Pizzi, A., Guyonnet, R., \& Jermannaud, A. (1999). Durability of Heat-treated Wood. IRG WP: International Research Group on Wood Preservation 30. Rosenheim, Germany. 6-11 ${ }^{\text {th }}$ June 1999.

Kocaefe, D., Chaudry, B., Ponscak, S., Bouazara, M., \& Pichette, A. (2007). Thermogravimetric Study of High Temperature Treatment of Aspen: Effect of Treatment Parameters on Weight Loss and Mechanical Properties. Journal of Material Science, 42(3), 854-866. http://dx.doi.org/10.1007/s10853-006-0054-3

Korkut, S., Kok, M. S., Korkut, D. S., \& Gurleyen, T. (2007). The Effects of Heat Treatment on Technological Properties in Red-Bud Maple (Acer trautvetteri Medw.) Wood. Journal of Bioresource Technology, 99(6), 1538-1543. http://dx.doi.org/10.1016/j.biortech.2007.04.021

Kotilainen, R. (2000). Chemical Changes in Wood During Heating at $150{ }^{\circ} \mathrm{C}-260{ }^{\circ} \mathrm{C}$. Ph.D Thesis. Jyvaskyla University, Finland.

Mburu, F., Dumarcay, S., Bocquet, J. F., Petrissans, M., \& Gerardin, P. (2008). Effect of Chemical Modifications Caused by Heat Treatment on Mechanical Properties of Grevillea robusta Wood. Journal of Polymer Degradation and Stability, 93(2), 401-405. http://dx.doi.org/10.1016/j.polymdegradstab.2007.11.017

Nurdahlia, A. S. (2008). Wood Quality of 10-Year-Old Sentang (Azadirachta excelsa) Grown from Seedlings and Rooted Cuttings. Master Thesis. University Putra Malaysia. 
Pinyopusarerk, K., LIANG, S. B., \& GUNN, B. V. (1993). Taxonomy, Distribution, Biology and Use as An Exotic. Proceeding of Acacia Mangium Growing and Utilization. Bangkok, Thailand. 1-19.

Rafidah, S., Razak, W., Zaidon, A., \& Hashim, W. S. (2009). Chemical Constituents of Bamboo Gigantochloa scortechinii oil-cured at $140{ }^{\circ} \mathrm{C}, 180{ }^{\circ} \mathrm{C}$ and $220{ }^{\circ} \mathrm{C}$. Journal of Applied Science, 9(1), 149-154. ISSN 1812-5654. Asian Network for Scientific Information.

Rafidah, S., Razak, W., \& Zaidon, S. (2008). Effect of Oil Thermally Modified on Chemical Constituents of Semantan Bamboo (Gigantochloa scortechinii Gamble). Journal of Sustainable Development, 1(2), 91-98. Canadian Center of Science and Education.

Razak, W., Izyan, K., Roziela, H., Othman, S., Aminuddin, M., \& Affendy, H. (2011). Effects of Hot Oil Treatment on Colour and Chemical Changes in year-old Cultivated Acacia hybrid. Journal of Tropical Forest Science (JTFS), 23(1), 42-50.

Razak, W., Aminuddin, M., Hashim, W. S., \& Othman, S. (2005). Effect of Heat Treatment Using Palm Oil on Properties and Durability of Semantan Bamboo. Journal of Bamboo and Rattan, 4(3), 211-220. ISSN: 1569-1568, International Network for Bamboo and Rattan.

Rowell, R. M., Pettersen, R., Han, J. S., Rowell, J. S., \& Tshabalala, M. A. (2005). Cell Wall Chemistry. In Rowell R.M. (ed.). Handbook of Wood Chemistry and Wood Composites, 37-72. Madison: CRC Press.

Rulliarty, S., \& America, W. A. (1995). Natural Variation in Wood Quality Indicators of Indonesian Big Leaf Mahogany(Swietenia macrophylla. King). XX IUFRO World Congress Proceedings, Tampere.

Rushe, H. (1973). Thermal Degradation of Wood at Temperatures up to $200{ }^{\circ} \mathrm{C}$. I. Strenght Properties of Wood After Heat Treatment. Journal of Holz als Roh-und Werkstoff, 31(7), 273-281.

Sailer, M., Rapp, A. O., \& Leithoff, H. (2000). Improved Resistance of Scots Pine by Application of an Oil thermally modified. International Research Group on Wood Preservation. Doc. No. IRG/WP 00-40162.

Sandermann, W., \& Augustin, H. (1964). Chemical Investigations on the Thermal Decomposition of Wood. Part III: Chemical Investigation on the Course of Decomposition. Journal of Holz als Roh-und Werkstoff, 22(10), 377-386. http://dx.doi.org/10.1007/BF02628346

Sarni, F., Moutounet, M., Puech, J. L., \& Rabier, P. (1990). Effect of Heat Treatment on Oak Wood Extractable Compounds. Journal of Holzforschung, 44(6), 461-466. http://dx.doi.org/10.1515/hfsg.1990.44.6.461

Shafizadeh, F. (1984). The Chemistry of Pyrolysis and Combustion. In The Chemistry of Solid Wood, Rowell, R.M. (Ed). ACS Symposium Series, 207, 489-529.

Smith, I., Landis, E., \& Gong, M. (2003). Structure and Properties of Wood. In Fracture and Fatigue in Wood, 7-34. Chichester: John Wiley \& Sons Ltd.

Stamm, A. J. (1964). Wood and Cellulose Science. The Ronald Press Co. New York.

Sundqvist, B. (2004). Colour Changes and Acid Formation in Wood during Heating. Ph.D. Thesis. Lulea University of Technology.

Technical Association of The Pulp and Paper Industry. (1999). TAPPI Standard T203 cm-99. Atlanta, USA.

Technical Association of The Pulp and Paper Industry. (2002). TAPPI Standard T222 cm-02. Atlanta, USA.

Viitaniemi, P. (2001). The Thermal Modification of Wood with Heat Treatment. VTT Building and Transport, 1-21, Espoo, Findland.

Yildiz, S., Gezer, E. D., \& Yildiz, U. C. (2006). Mechanical and Chemical Behaviour of Spruce Wood Modified by Heat. Journal of Building and Environment, 41(12), 1762-1766. http://dx.doi.org/10.1016/j.buildenv.2005.07.017

Wikberg, H., \& Maunu, S. L. (2004). Characterization of thermally modified hardwoods and softwoods by $13 \mathrm{C}$ CPMAS NMR. Carbohydrate Polymers, 58(4), 461-466. http://dx.doi.org/10.1016/j.carbpol.2004.08.008 
Table 1. Average values of chemical changes of 15-year-old oil heat-treated Acacia hybrid wood

\begin{tabular}{|c|c|c|c|c|c|c|}
\hline \multirow{2}{*}{ Wood type } & \multirow{2}{*}{ Temp. $\left({ }^{\circ} \mathrm{C}\right)$} & \multirow{2}{*}{$\begin{array}{c}\text { Treatment } \\
\text { duration (min) }\end{array}$} & \multicolumn{4}{|c|}{ Chemical Composition (\%) } \\
\hline & & & Holocellulose & Cellulose & Hemicellulose & Lignin \\
\hline \multirow{10}{*}{ Sapwood } & Control & Control & 71.5 & 47.1 & 24.4 & 20.8 \\
\hline & & 30 & $70.8(-1.0)$ & $46.2(-1.9)$ & $24.6(0.8)$ & $20.7(-0.5)$ \\
\hline & 180 & 60 & $69.7(-2.5)$ & $45.1(-4.2)$ & $24.6(0.8)$ & $22.0(5.8)$ \\
\hline & & 90 & $66.6(-6.9)$ & $43.6(-7.4$ & $23.0(-5.7)$ & $22.1(6.3)$ \\
\hline & & 30 & $68.6(-4.1)$ & $42.5(-9.8)$ & $26.1(7.0)$ & $23.9(14.9)$ \\
\hline & 200 & 60 & $65.3(-8.7)$ & $39.2(-16.8)$ & $26.0(6.6)$ & $23.8(14.4)$ \\
\hline & & 90 & $64.5(-9.8)$ & $38.5(-18.3)$ & $26.0(6.6)$ & $24.7(18.8)$ \\
\hline & & 30 & $66.4(-7.1)$ & $41.6(-11.7)$ & $24.8(1.6)$ & $23.7(13.9)$ \\
\hline & 220 & 60 & $64.9(-9.2)$ & $38.9(-17.4)$ & $26.0(6.6)$ & $24.3(16.8)$ \\
\hline & & 90 & $63.1(-11.7)$ & $37.7(-20.0)$ & $25.4(4.1)$ & $24.0(15.4)$ \\
\hline \multirow{10}{*}{ Heartwood } & Control & Control & 73.4 & 48.9 & 24.5 & 22.4 \\
\hline & & 30 & $71.7(-2.3)$ & $47.8(-2.3)$ & $23.9(-2.5)$ & $21.7(-3.1)$ \\
\hline & 180 & 60 & $70.6(-3.8)$ & $46.3(-5.3)$ & $24.3(-0.8)$ & $22.9(2.2)$ \\
\hline & & 90 & $67.9(7.5)$ & $44.7(-8.6)$ & $23.2(-5.3)$ & $23.0(2.7)$ \\
\hline & & 30 & $68.8(-6.3)$ & $42.6(-12.9)$ & $25.9(5.7)$ & $24.5(9.4)$ \\
\hline & 200 & 60 & $68.3(-6.9)$ & $42.1(-14.0)$ & $26.2(6.9)$ & $24.9(11.2)$ \\
\hline & & 90 & $66.5(-9.4)$ & $40.9(-16.4)$ & $25.6(4.5)$ & $25.0(11.6)$ \\
\hline & & 30 & $67.1(-8.6)$ & $42.0(-14.1)$ & 25.7 (4.9) & $24.7(10.3)$ \\
\hline & 220 & 60 & $65.1(-11.3)$ & $39.7(-18.8)$ & $25.4(3.7)$ & $24.8(10.7)$ \\
\hline & & 90 & $64.0(-12.8)$ & $38.1(-22.1)$ & $25.9(5.7)$ & $24.9(11.2)$ \\
\hline
\end{tabular}

( ) $=\%$ change from control

Note: Holocellulose is the total polysaccharide fraction of wood that is composed of cellulose and all of the hemicelluloses and what is obtained when the extractives and lignin are removed from the natural material. 
Table 2. Average values of bending strength (MOR and MOE) of sapwood and heartwood Acacia hybrid through oil-heat treatment process

\begin{tabular}{|c|c|c|c|c|c|c|c|c|}
\hline \multirow{2}{*}{ Wood Type } & \multirow{2}{*}{ Temp. $\left({ }^{\circ} \mathrm{C}\right)$} & \multirow{2}{*}{$\begin{array}{c}\text { Treatment } \\
\text { duration (min) }\end{array}$} & \multicolumn{3}{|c|}{$\operatorname{MOR}\left(\mathrm{N} / \mathrm{mm}^{2}\right)$} & \multicolumn{3}{|c|}{$\operatorname{MOE}\left(\mathrm{N} / \mathrm{mm}^{2}\right)$} \\
\hline & & & B & M & $\mathrm{T}$ & $\mathrm{B}$ & M & $\mathrm{T}$ \\
\hline \multirow{10}{*}{ Sapwood } & Control & Control & 69.78 & 67.22 & 65.08 & 3864.54 & 3803.57 & 3776.72 \\
\hline & \multirow{3}{*}{180} & 30 & $\begin{array}{l}64.05 \\
(8.21)\end{array}$ & $\begin{array}{l}61.98 \\
(7.80)\end{array}$ & $\begin{array}{l}63.37 \\
(2.63)\end{array}$ & $\begin{array}{l}3535.7 \\
(8.51)\end{array}$ & $\begin{array}{c}3455.43 \\
(9.15)\end{array}$ & $\begin{array}{c}3492.52 \\
(7.53)\end{array}$ \\
\hline & & 60 & $\begin{array}{l}63.43 \\
(9.10)\end{array}$ & $\begin{array}{c}59.66 \\
(11.25)\end{array}$ & $\begin{array}{c}52.23 \\
(19.74)\end{array}$ & $\begin{array}{l}3475.95 \\
(10.06)\end{array}$ & $\begin{array}{r}3416.45 \\
(10.18)\end{array}$ & $\begin{array}{l}3265.79 \\
(13.53)\end{array}$ \\
\hline & & 90 & $\begin{array}{c}62.31 \\
(10.71)\end{array}$ & $\begin{array}{c}55.82 \\
(16.96)\end{array}$ & $\begin{array}{c}47.99 \\
(26.26)\end{array}$ & $\begin{array}{r}3470.29 \\
(10.20)\end{array}$ & $\begin{array}{c}3412.22 \\
(10.29)\end{array}$ & $\begin{array}{l}3207.16 \\
(15.08)\end{array}$ \\
\hline & \multirow{3}{*}{200} & 30 & $\begin{array}{l}55.06 \\
(11.64)\end{array}$ & $\begin{array}{l}54.85 \\
(18.40)\end{array}$ & $\begin{array}{c}45.31 \\
(30.28)\end{array}$ & $\begin{array}{r}3407.97 \\
(11.81)\end{array}$ & $\begin{array}{c}3328.01 \\
(12.50)\end{array}$ & $\begin{array}{l}3094.19 \\
(18.07)\end{array}$ \\
\hline & & 60 & $\begin{array}{c}60.11 \\
(13.86)\end{array}$ & $\begin{array}{c}54.70 \\
(18.63)\end{array}$ & $\begin{array}{l}44.86 \\
(31.07)\end{array}$ & $\begin{array}{c}3333.09 \\
(13.75)\end{array}$ & $\begin{array}{c}3228.98 \\
(15.11)\end{array}$ & $\begin{array}{l}3035.35 \\
(19.63)\end{array}$ \\
\hline & & 90 & $\begin{array}{c}55.38 \\
(20.64)\end{array}$ & $\begin{array}{c}50.41 \\
(25.01)\end{array}$ & $\begin{array}{c}42.85 \\
(34.16)\end{array}$ & $\begin{array}{l}3244.75 \\
(16.04)\end{array}$ & $\begin{array}{c}3172.19 \\
(16.60)\end{array}$ & $\begin{array}{r}2972.25 \\
(21.30)\end{array}$ \\
\hline & \multirow{3}{*}{220} & 30 & $\begin{array}{c}53.9 \\
(22.76)\end{array}$ & $\begin{array}{c}49.72 \\
(26.03)\end{array}$ & $\begin{array}{c}40.57 \\
(37.66)\end{array}$ & $\begin{array}{l}3216.75 \\
(16.76)\end{array}$ & $\begin{array}{l}3101.06 \\
(18.47)\end{array}$ & $\begin{array}{l}2938.18 \\
(22.20)\end{array}$ \\
\hline & & 60 & $\begin{array}{c}51.42 \\
(26.31)\end{array}$ & $\begin{array}{c}46.89 \\
(30.14)\end{array}$ & $\begin{array}{l}38.15 \\
(41.38)\end{array}$ & $\begin{array}{l}3133.38 \\
(18.92)\end{array}$ & $\begin{array}{c}3046.50 \\
(19.90)\end{array}$ & $\begin{array}{r}2716.33 \\
(28.08)\end{array}$ \\
\hline & & 90 & $\begin{array}{c}41.21 \\
(40.94)\end{array}$ & $\begin{array}{c}40.33 \\
(40.00)\end{array}$ & $\begin{array}{c}37.03 \\
(43.10)\end{array}$ & $\begin{array}{c}3001.51 \\
(22.33)\end{array}$ & $\begin{array}{c}2787.39 \\
(26.72)\end{array}$ & $\begin{array}{r}2599.31 \\
(31.18)\end{array}$ \\
\hline & Control & Control & 68.51 & 70.76 & 90.43 & 3975.49 & 4004.07 & 4067.94 \\
\hline \multirow{9}{*}{ Heartwood } & \multirow{6}{*}{200} & 30 & $\begin{array}{l}67.42 \\
(1.59)\end{array}$ & $\begin{array}{l}65.24 \\
(7.80)\end{array}$ & $\begin{array}{l}66.70 \\
(26.24)\end{array}$ & $\begin{array}{c}3676.91 \\
(7.51)\end{array}$ & $\begin{array}{c}3637.29 \\
(9.16)\end{array}$ & $\begin{array}{c}3721.56 \\
(8.51)\end{array}$ \\
\hline & & 60 & $\begin{array}{l}66.77 \\
(2.54)\end{array}$ & $\begin{array}{c}63.47 \\
(10.30)\end{array}$ & $\begin{array}{c}54.98 \\
(39.20)\end{array}$ & $\begin{array}{l}3658.9 \\
(7.96)\end{array}$ & $\begin{array}{c}3634.52 \\
(9.23)\end{array}$ & $\begin{array}{l}3437.94 \\
(15.49)\end{array}$ \\
\hline & & 90 & $\begin{array}{l}65.59 \\
(4.26)\end{array}$ & $\begin{array}{c}58.81 \\
(16.89)\end{array}$ & $\begin{array}{c}51.06 \\
(43.54)\end{array}$ & $\begin{array}{c}3587.34 \\
(9.76)\end{array}$ & $\begin{array}{c}3599.88 \\
(10.09)\end{array}$ & $\begin{array}{l}3376.74 \\
(16.08)\end{array}$ \\
\hline & & 30 & $\begin{array}{l}63.27 \\
(7.65)\end{array}$ & $\begin{array}{c}58.75 \\
(16.97)\end{array}$ & $\begin{array}{c}47.74 \\
(47.21)\end{array}$ & $\begin{array}{l}3577.19 \\
(10.02)\end{array}$ & $\begin{array}{c}3547.83 \\
(11.39)\end{array}$ & $\begin{array}{l}3291.87 \\
(19.08)\end{array}$ \\
\hline & & 60 & $\begin{array}{c}58.8 \\
(14.17)\end{array}$ & $\begin{array}{c}57.74 \\
(18.40)\end{array}$ & $\begin{array}{c}47.7 \\
(47.25)\end{array}$ & $\begin{array}{c}3545.84 \\
(10.81)\end{array}$ & $\begin{array}{r}3503.17 \\
(12.51)\end{array}$ & $\begin{array}{l}3229.33 \\
(20.62)\end{array}$ \\
\hline & & 90 & $\begin{array}{c}58.57 \\
(14.51)\end{array}$ & $\begin{array}{c}53.63 \\
(24.21)\end{array}$ & $\begin{array}{c}45.67 \\
(49.50)\end{array}$ & $\begin{array}{c}3488.98 \\
(12.24)\end{array}$ & $\begin{array}{c}3435.31 \\
(14.20)\end{array}$ & $\begin{array}{l}3162.30 \\
(22.26)\end{array}$ \\
\hline & \multirow{3}{*}{220} & 30 & $\begin{array}{c}57.96 \\
(15.40)\end{array}$ & $\begin{array}{c}52.89 \\
(25.25)\end{array}$ & $\begin{array}{c}43.62 \\
(51.76)\end{array}$ & $\begin{array}{c}3422.08 \\
(13.92)\end{array}$ & $\begin{array}{c}3299.28 \\
(17.60)\end{array}$ & $\begin{array}{l}3159.49 \\
(22.33)\end{array}$ \\
\hline & & 60 & $\begin{array}{c}55.30 \\
(19.28)\end{array}$ & $\begin{array}{c}50.42 \\
(28.75)\end{array}$ & $\begin{array}{c}41.02 \\
(54.6()\end{array}$ & $\begin{array}{c}3369.22 \\
(15.25)\end{array}$ & $\begin{array}{c}3275.80 \\
(18.19)\end{array}$ & $\begin{array}{r}2920.83 \\
(28.20)\end{array}$ \\
\hline & & 90 & $\begin{array}{c}44.31 \\
(35.32)\end{array}$ & $\begin{array}{c}44.7 \\
(36.83)\end{array}$ & $\begin{array}{c}39.81 \\
(55.98)\end{array}$ & $\begin{array}{c}2997.64 \\
(24.60)\end{array}$ & $\begin{array}{c}3227.43 \\
(19.40)\end{array}$ & $\begin{array}{r}2794.95 \\
(31.29)\end{array}$ \\
\hline
\end{tabular}

Note: $\{\quad\}=\%$ change from control samples, $\mathrm{B}=$ Bottom, $\mathrm{M}=$ Middle, $\mathrm{T}=$ Top. 
Table 3. ANOVA on the strength properties of oil heat treated Acacia hybrid

\begin{tabular}{lccccc}
\hline $\begin{array}{l}\text { Source of } \\
\text { Variance }\end{array}$ & $\begin{array}{c}\text { Dependent } \\
\text { Variable }\end{array}$ & Sum of Squares & Df & Mean Square & F-Ratio \\
\hline Temperature & MOR & 12076.80 & 3 & 4025.59 & $15.99^{* *}$ \\
& MOE & 1.81 & 3 & 6.02 & $12.66^{* *}$ \\
Duration & MOR & 3425.40 & 2 & 1712.70 & $6.80^{* *}$ \\
& MOE & 2.72 & 2 & 1.36 & $2.86^{\text {ns }}$ \\
Wood Types & MOR & 565.80 & 1 & 565.80 & $2.25^{\text {ns }}$ \\
(Sap and & MOE & 2.16 & 1 & 2.16 & $4.55^{*}$ \\
Heartwood) & & & & \\
Sampling & MOR & 3098.58 & 2 & 1549.29 & $6.15^{* *}$ \\
Height & 2.06 & 2 & 1.03 & $2.17^{\text {ns }}$ \\
\hline
\end{tabular}

Table 4. ANOVA on chemical compositions of oil heat treated 15 year-old Acacia hybrid

\begin{tabular}{lccccc}
\hline \multirow{2}{*}{ Source of Variance } & Dependent Variable & $\begin{array}{c}\text { Sum of } \\
\text { Squares }\end{array}$ & Df & Mean Square & F-Ratio \\
\hline \multirow{2}{*}{ Temperature } & Holocellulose & 1618.96 & 3 & 539.65 & $564.15^{* *}$ \\
& Hemicellulose & 139.12 & 3 & 46.37 & $85.82^{* *}$ \\
& Cellulose & 2460.23 & 3 & 820.08 & $1018.75^{* *}$ \\
& Lignin & 368.90 & 3 & 122.97 & $461.45^{* *}$ \\
Duration & Holocellulose & 250.82 & 2 & 125.41 & $131.10^{* *}$ \\
& Hemicellulose & 7.43 & 2 & 3.72 & $6.88^{* *}$ \\
Cellulose & 210.26 & 2 & 105.13 & $130.60^{* *}$ \\
Lood types & Lignin & 12.69 & 2 & 6.35 & $23.81^{* *}$ \\
(Sap and & Holocellulose & 96.80 & 1 & 96.80 & $101.20^{* *}$ \\
Heartwood) & Hemicellulose & 0.01 & 1 & 0.01 & $0.01^{\mathrm{ns}}$ \\
& Cellulose & 95.20 & 1 & 95.20 & $118.27^{* *}$ \\
& Lignin & 52.22 & 1 & 52.22 & $195.94^{* *}$ \\
\hline
\end{tabular}


Table 5. Correlations analysis between chemical and strength properties of oil heat treated 15 year-old cultivated Acacia hybrid

\begin{tabular}{lcccccc}
\hline Wood Properties & MOR & MOE & Holocellulose & Hemicellulose & Cellulose & Lignin \\
\hline MOR & 1 & $0.60^{* *}$ & $0.42^{* *}$ & $-0.19^{*}$ & $0.42^{* *}$ & $-0.36^{* *}$ \\
MOE & & 1 & $0.35^{* *}$ & $-0.24^{* *}$ & $0.37^{* *}$ & $-0.31^{* *}$ \\
Holocellulose & & & 1 & $-0.34^{* *}$ & $0.96^{* *}$ & $-0.69^{* *}$ \\
Hemicellulose & & & & 1 & $-0.59^{* *}$ & $0.61^{* *}$ \\
Cellulose & & & & 1 & $-0.77^{* *}$ \\
Lignin & & & & 1 \\
\hline
\end{tabular}

Note: Total number of wood $=216, * *=$ significant at $\mathrm{p} \leq 0.01, *=$ significant at $\mathrm{p} \leq 0.05$, ns $=$ not significant, $\mathrm{MC}=$ Moisture Content, $\mathrm{BD}=$ Basic Density, $\mathrm{MOR}=$ Modulus of Rupture, $\mathrm{MOE}=$ Modulus of Elasticity . 